\title{
A PILLAR OF ACADEMIC AND RESEARCH EXCELLENCE: THE ENDURING INFLUENCE OF MENTORSHIP IN SCIENCE
}

\author{
C L Soskolne, Professor Emeritus, University of Alberta, Canada; and Adjunct Professor, Faculty of Health, University of Canberra, Australia \\ colin.soskolne@ualberta.ca
}

\section{Why mentorship?}

Regardless of one's focus in science, instilled intellectual honesty and rigour are the fruits of proper mentoring. The importance of intellectual rigour through one's period of training - by example - cannot be overstated. Proper mentoring includes not only the ethically correct application of learned skills, but, at least as importantly, collegiality through respectful and honourable conduct, and of friendship through a shared set of values and interests aligned with the pursuit of intellectual honesty.

The lessons learned through proper mentorship are essential and should be passed on to the next generation of aspiring scientists if the sciences are to flourish. Humility and excellence in our pursuit of truth, towards an ever-greater understanding of our world and its place in the universe, are perhaps the two most pertinent principles associated with proper mentorship.

Curiosity, passion for, and excellence in applying research methods, as well as diligence in leadership by example are all essential characteristics found only in the best of mentors. The influence of these characteristics on those entering the professions creates a generation imbued with a striving for excellence. Those fortunate enough to have been at the right place at the right time, and to have been able to recognise the opportunity to pursue intellectual honesty with rigour, will know that science is their calling. Proper mentorship thus provides the model exemplar for the next generation of scientists.

\section{A case study on the influence of proper mentorship}

In 1969, at the formative stage of completing an advanced degree (BSc Hons), my career was profoundly influenced through the serendipitous meeting of the then-newly arrived in South Africa British physician-scientist, Dr Peter H Beighton. The meeting took place in the Department of Applied Mathematics and Computer Science at the University of the Witwatersrand. As a graduate student in the department, I was into the computerisation of survey data. Dr Beighton had just arrived in South Africa with his wife and research associate, Greta Beighton, to undertake his doctoral studies on the epidemiology of bone and joint diseases.

Dr Beighton was seeking the collaboration of a statistician with survey design and computerisation skills. I was able to fulfil some of these functions for about 8 years after becoming integral to the team led by Dr Beighton. This collaboration resulted not only in Dr Beighton's successful $\mathrm{PhD}$, but also in a productive period in co-authoring with Dr Beighton - soon to become Professor Beighton - numerous pioneering papers relating to the epidemiology of bone and joint diseases in southern Africa. It was this experience that instilled in me the critical importance and value of proper mentorship.

Peter Beighton exposed me to the rigours of population health research $(1969$ - 1977). This led to my realisation that this was where my interests in fact lay. As a result, I then transferred from my initial work with the Human Sciences Research Council in Pretoria (1970 1973), with a focus on education research, to join the National Research Institute for Occupational Diseases (later to become the National Centre for Occupational Health) in Johannesburg (1973 1977), with a focus on population health research. It was this latter work experience that put me onto a path of occupational and environmental epidemiology that led to my leaving South Africa at the end of 1977 to undertake my $\mathrm{PhD}$ studies at the University of Pennsylvania, Philadelphia, US. I have been based in Canada ever since.

My focus thus had shifted from the epidemiology of bone and joint diseases to the epidemiology of occupational and environmental health. The lessons learned through the years of collaboration with Peter Beighton stood me in good stead, not only in achieving my calling but also through a career that was fraught with ethical challenges. Let me explain the relevance of this experience in today's world and how this could be of relevance to young scholars wherever in the world they are based.

If it had not been for the value placed on intellectual honesty, my continued career contributions to research and training could not have been sustained. The forces of self-interest that operate in the world can have a terribly negative influence on one's pursuit of intellectual honesty. With the conscious or subconscious drive to pursue science with intellectual honesty, I came to recognise that great vigilance is needed to keep our house of science in order, including an awareness of the drivers of dishonesty in science. Hence, much of my career has been devoted to advancing ethics in the profession of epidemiology.

\section{Some of the lessons learned}

Through proper mentorship, the ethic of science is not only a theoretical construct, but it becomes a lived experience. The scientific ethic is a duty-based ethic that requires of scientists ${ }^{[1]}$ that they:

- use appropriate methods

- be objective

- be honest in reporting

- publish results whether the findings demonstrate a positive effect, a negative effect or no effect

- prohibit distortion in, for example:

- the falsification of data

- bias inherent to study design

- proper analytical procedures

- objectivity in one's interpretation of the data

- do one's own work:

- do not plagiarise

- acknowledge sources

- do not exploit graduate students. 
These duties apply to scientists wherever in the world they are based. They are more meaningfully demonstrated in the real world of practice than in the classroom, detached from field experience. These duties are profound because we live in a world where moneyed influence can corrupt our very thought processes. However, being shown through proper mentorship how to navigate the minefield of temptation to misuse one's skills rather than to remain true to the mission of science is a value that only role models can impart through proper mentorship.

\section{The forces that can lead scientists astray}

In life, people are inclined to cut corners or to take the easier path. Scientists are people and can be distracted by other life pressures and can also be seduced by the temptation of money and fame. Proper mentorship will set an example where such actions are not even an option.

The role of the mentor thus becomes critical in demonstrating good judgment and in doing the right thing for the right reason. The emphasis is intellectual honesty through the rigorous application of methods, leaving no stone unturned in the pursuit of truth.

The pursuit of truth through excellence has its own rewards. The goal of the scientist is to generate the most valid evidence possible to help advance the public good. Scientists should not cause harm through the misuse of the skills acquired through their training. Proper mentorship serves to help the young scientist distinguish the ethical from the unethical. There will always be forces of influence to tempt the scientist away from the pursuit of truth, but the ethical scientist will remain true to the mission of science.

Should circumstances change such that the mentor can no longer remain true to the mission of science, then, instead of succumbing, the ethical scientist will try to correct the circumstances, which could lead to a change in career or position. However, in reality, many scientists, especially those who have achieved a level of economic security as well as of academic prestige and responsibility, may not choose to jeopardise their status and/or put at risk their research programmes by trying either to influence or perhaps leave their institutions. It is here where we see the system break down. How do such circumstances arise?

Today, with ever-growing ties between academe and industry owing to the relatively smaller proportion of public money allocated by governments to research, economic pressures make the role of mentors in reinforcing the values and ethics of science less possible. Since the 1970s when I was mentored, the world has changed in that ethical tensions in navigating the increasing influence of political and funding-source pressures are being experienced by our profession as well as by the organisations/institutions that employ us. The problem is systemic. This has resulted in serious challenges to the moral foundations of today's mentors. The temptation of a substantial stream of income, both personally to the scientist as well as for their research programmes, especially those from corporate sponsors, may be corrupting and is not uncommon. When the mentors are subjected to these pressures, which is, in my experience, the case even in the most esteemed universities, the mentorship process breaks down. ${ }^{[2,3]}$

Many examples exist where science has been misused to deceive and mislead. In such instances, it has derailed the pursuit of truth and harmed the public interest. Examples of the industry of fomenting uncertainty and casting doubt about valid science are welldocumented in environmental health research more broadly, ${ }^{[4-6]}$ and in epidemiology research areas of tobacco, ${ }^{[7]}$ cancer ${ }^{[8]}$ asbestos, ${ }^{[9,10]}$ and climate change. ${ }^{[7,11]}$

This contribution to a festschrift to honour the work of Peter Beighton is not the place to expound on these examples, other than to provide them as references to classic texts. In particular, inspired by much that I learned from Peter Beighton, the ethical learnings from my personal experience through my doctoral training in the USA ${ }^{[12]}$ resulted in my initiative to promote the need for ethics guidelines for my then-newly entered profession of epidemiology. ${ }^{[13]}$ It is on the shoulders of others that we advance the good done by them. Thank you, Peter, as I reflect on all that you contributed to in my own growth and maturity as a scientist.

Acknowledgement. Thanks to Dr Shira Kramer for her review of and suggestions to improve the penultimate draft of this article.

\footnotetext{
1. Reece RD, Siegal HA. Studying People: A Primer in the Ethics of Social Research. Macon: Mercer 1986:62-70

2. Heath D, Center for Public Integrity. Lauded public health researcher also worked for industry revealing entanglements of science. 2013. http://www.publicintegrity.org/2013/12/20/14039/ revealing entanglements of science. 2013. http://wWw.publicintegrity.org/2013/12/20/14039/
lauded-public-health-researcher-also-worked-industry-revealing-entanglements (accessed 13 lauded-public-

April 2016)

3. Heath D, Center for Public Integrity. Science for sale. Meet the 'rented white coats' who defend toxic chemicals: How corporate-funded research is corrupting America's courts and regulatory agencies. 2016. http://www.publicintegrity.org/2016/02/08/19223/meet-rented-white-coats-who-defend-toxic chemicals (accessed 13 April 2016)

4. Davis $\mathrm{D}$. When smoke ran like water: Tales of environmental deception and the battle against pollution New York: Basic Books, 2002.

5. Michaels D. Doubt is their product: How industry's assault on science threatens your health. New York Oxford University Press, 2008

6. Brown DA. The ominous rise of ideological think tanks in environmental policy-making. In: Soskolne CL, ed. Sustaining Life on Earth: Environmental and Human Health Through Global Governance. Lanham: Lexington Books, 2008:243-256.

7. Oreskes N, Conway EM. Merchants of doubt: How a handful of scientists obscured the truth on issue from tobacco smoke to global warming. London: Bloomsbury Press, 2010.

8. Davis D. The secret history of the war on cancer. New York: Basic Books, 2007.

9. McCulloch J, Tweedale G. Defending the indefensible: The global asbestos industry and its fight for McCulloch J, Tweedale G. Defending the indefens
survival. New York: Oxford University Press, 2008.

survival. New York: Oxford University Press, 2008.
10. Baur X, Budnik LT, Ruff K, Egilman DS, Lemen RA, Soskolne CL. Ethics, morality, and conflicting Baur X, Budnik LT, Ruff K, Egilman DS, Lemen RA, Soskolne CL. Ethics, morality, and conflicting
interests: How questionable professional integrity in some scientists supports global corporate influence in public health. Int J Occup Environ Health 2015;21(2):172-175. DOI:10.1179/20493967 4Y.0000000103

11. Ethics and Climate BLOG. The seeds of the corporate funded climate disinformation campaign, the 1971 Lewis Powell Memo. 2015. http://ethicsandclimate.org/2015/10/31/the-seeds-of-the-corporatefunded-climate-disinformation-campaign-the-1971-lewis-powell-memo/ (accessed 17 Novembe 2015).

12. Soskolne CL. Epidemiological research, interest groups, and the review process. J Public Health Policy 1985;6(2):173-184

3. Soskolne CL. Epidemiology: Questions of science, ethics, morality and law. Am J Epidemiol 1989;129(1):1-18.
}

S Afr Med J 2016;106(6 Suppl 1):S12-S13. DOI:10.7196/SAMJ.2016.v106i6.11024 